\title{
An Analysis of Constraints Faced by Gaushalas in Haryana
}

\author{
Shweta Bijla ${ }^{1 *}$, Khalandar S. ${ }^{2}$, Priya Sharma ${ }^{3}$ and Ajmer Singh ${ }^{1}$ \\ ${ }^{1}$ Division of Dairy Economics, Statistics and Management, ICAR- National Dairy Research Institute, Karnal, Haryana, India \\ ${ }^{2}$ Department of Forestry, Dr. Y S Parmar University of Horticulture and Forestry, Nauni, Solan, Himachal Pradesh, India \\ ${ }^{3}$ Division of Dairy Extension, ICAR- National Dairy Research Institute, Karnal- 132001, Haryana, India
}

*Corresponding author: shwetabijla00@gmail.com

\begin{abstract}
Cow is venerated by more than 70 per cent of the population of our country. Although the total cattle population of the country is dominated by indigenous cattle but the population of crossbred cattle has increased significantly. There is also another problem of large number of stray cattle in the country and their number is still increasing. They need to be managed. Gaushalas are considered to be a good alternative to manage the ever increasing stray cattle population. Since Gaushalas are supported by charity and have to take care of unproductive animals, they face various constraints in managing these uneconomical cattle. Thus a study was conducted to identify and prioritize the constraints faced by Gaushalas in Haryana. A detailed questionnaire in respect to various aspects of housing, feeding, breeding, marketing, institutional, labour, waste disposal and animal health constraints were enlisted and Gaushalas' committee members were asked to rank each constraint which were later analyzed through Garret's ranking method. The major overall constraints found in the study area were lack of green fodder (71.40), high cost of concentrates (67.44), irregular government grants (62.95), lack of space (62.55) and inadequate market information (62.10).
\end{abstract}

Keywords: Constraint, Garret ranking method, housing, feeding, breeding, marketing, institutional, labour, waste disposal, animal health

Earlier India was not much competent in agriculture sector in the world but the two turning points in Indian history i.e. "Green Revolution" and "White Revolution" have changed the scenario of Indian agriculture significantly over the years. Livestock sector currently contributes 19 per cent to agricultural GDP. India is having more then half of the cattle of the world. Total cattle population is dominated by indigenous cattle with 79 per cent share as against 21 per cent share of crossbred cattle, but the population of crossbred cattle has increased significantly from 7 per cent in 1992 to 21 per cent in 2012, while those of indigenous cattle has declined from 93 per cent in 1992 to 79 per cent in last census conducted in 2012 (19 ${ }^{\text {th }}$ Livestock Census, 2012). This situation sounds the alarm as the diverse genetic base of India is becoming narrow. The main reason for such a declining trend in the population of indigenous cattle can be considered as abandoning of these cattle once they pass their milking stage and become uneconomical to the farmers. As soon as milk yield of cow declines after $7^{\text {th }}$ or $8^{\text {th }}$ lactation, farmers try to abandon these animals as soon as possible. The reason can be fodder and feed which they want to save for productive animals. Then these unwanted animals will be either seen foraging in garbage dumps in the cities or will finish up at slaughter house. But cow slaughter is banned in India due to religious taboos. Both cow slaughter and sale of beef are cognizable and non-bailable offences in some states, asking for five to ten years of strict imprisonment and fine.

But all these things like abandoning of unproductive cattle, ban on beef and further strict penalties on their transportation outside the states has led to another problem of stray cattle in the country which is markedly a lot more difficult to deal with. In the cities, there are bunches of cows and 
bulls crouching in the centre of roads which have become a metaphor for strong debate on ban on their slaughter. At present total number of stray cattle in India are 52, 87,767 (19 th $^{\text {th }}$ Livestock Census, 2012). They hinder with normal lives of people cause traffic jams and are one of the major causes of road accidents. They also lead to crop losses by grazing farmers' fields.

Solutions to these problems are complex because of the social taboos and various religious sentiments attached to it. There are several attempts to relax the rules on slaughter ban but the states currently making their bans stricter. Farmers are poor and have fewer options. Thus, there is a need to find alternative way to manage these animals. The solution lies in maintaining the dairies adequately, creating huge Gaushalas with adequate space and funds, at appropriate locations, which can house thousands of such cattle and proper public and government cooperation. But keeping above points in view, majority of cattle found in Gaushalas are unproductive and uneconomical, thus for managing these animals, Gaushalas are mostly dependent on donations, charity and grants. These institutions are facing various problems on economic front due to lack of government support, delays in funding, less space and feed availability etc. In case of fodder supply in India, it is extremely scarce and the gap is very wide. During 2005-06 against the demand for green fodder, dry fodder and concentrates, we were able to meet only 38 per cent, 78 per cent and 37 per cent respectively (Hedge, 2006). The recommended ratio of veterinarian to veterinary institute is 1:5000 which is still not achieved (Yashada, 2006). Thus, these institutions need focused attention particularly to know and prioritize the problems faced by them so that they can be made sustainable. With this point of view an attempt has been made to study the various constraints faced by Gaushalas in certain areas of housing, feeding, breeding etc.

\section{Data and Methodology}

Haryana state was selected purposively for the study. Based on the information available at official site of Haryana Gaushala Sangh, Department of Animal Husbandry and Dairying, Government of Haryana and other sources such as Gaushala activities, one feasible Gaushala was selected from each of the ten selected district. From the eastern side Ambala,
Yamunanagar, Karnal, Panipat and Kurukshetra were selected; from the central region Kaithal and Rohtak were selected and Hisar, Bhiwani and Jind were selected from western region of Haryana. For ranking the constraints faced by Gaushalas ten respondents from each Gaushalas were selected at random. Thus a total of 100 respondents were selected for giving ranks to different constraints.

\section{Scoring of the constraints and ranking}

For ranking of these constraints, Garrett Ranking method was used. A questionnaire of constraints was prepared and ten respondents from each Gaushala were selected and asked to assign the rank to all the constraints and the outcome of such ranking was converted into score value with the help of the following formula:

$$
\text { Percent position }=100^{*}\left(R_{i j}-0.5\right) / N_{j}
$$

Here, $R_{i j}=$ Rank given for the $i^{\text {th }}$ variable by $j^{\text {th }}$ respondent, $N_{j}=$ Number of variable ranked by $j^{\text {th }}$ respondent.

With the help of Garrett's Table (Garrett and Woodworth, 1969) the percent position estimated was converted into scores. Then for each factor, the scores of each individual respondent were added together and divided by the total number of the respondents for whom scores are added. These mean scores for all the factors were arranged in descending order and the constraints were ranked accordingly. The constraint having highest mean score was considered to be the most important constraint in its respective category.

\section{RESULTS AND DISCUSSION}

The constraints here imply the problems faced by the executors of Gaushalas in maintaining such a large population of cattle most of which are unproductive and uneconomical. According to the Gaushalas' conditions the constraints were categorized into nine groups i.e. housing, feeding, breeding, marketing, labour, institutional, waste disposal, financial and health constraints. The responses on commonly occurring problems in the Gaushalas given by the respondents in the study area were arranged and analyzed by using Garret ranking technique and results along with mean scores are presented in table 1 to table 10 . 
The housing constraints are presented in table 1 and the major constraints were less space availability to animals (62.55) followed by poor quality of roofing material (48.45).

Table 1: Housing constraints faced by the Gaushalas

\begin{tabular}{lcc}
\hline Housing Constraints & Average Scores & Rank \\
\hline Less Space (shed) & 62.55 & 1 \\
Less Space (open) & 52.95 & 2 \\
Poor quality roofing material & 48.45 & 3 \\
Lack of Cleanliness & 47.05 & 4 \\
Lack of provision of cooling in & 39.00 & 5 \\
summer & &
\end{tabular}

The feeding constraints are given in table 2 and the major feeding constraints were lack of green fodder (71.40), and high cost of concentrates (67.44) and lack of dry fodder (60.71) followed by less land availability for fodder cultivation and low availability of concentrates etc. Similar findings were reported by Misra and Pal (2003), Singh and Chauhan (2006), Kaur et al. (2011), Dhindsa et al. (2014) Nagrale et al. (2014) in various states of India.

Table 2: Feeding constraints faced by the Gaushalas

\begin{tabular}{lcc}
\hline Feeding Constraints & Average Score & Rank \\
Lack of green fodder availability & 71.40 & 1 \\
High cost of concentrates & 67.44 & 2 \\
Lack of dry fodder availability & 60.71 & 3 \\
Lack of land for fodder & 55.87 & 4 \\
cultivation & & \\
Lack of concentrates & 55.86 & 5 \\
Unbalanced feeding & 45.60 & 6 \\
Less fodder storage space & 38.50 & 7 \\
Low quality of drinking water & 37.28 & 8 \\
\hline
\end{tabular}

The breeding constraints are presented in Table 3 and the major breeding constraints were incidence of reproductive disorder (60.65) and low conception rate (58.90). Similar findings were reported by Mohi and Bhatti (2006) in Punjab and by Patel et al. (2013) in Gujarat, where poor conception rate and poor A.I. results were found as major constraints.

Table 3: Breeding constraints faced by the Gaushalas

\begin{tabular}{lcc}
\hline Breeding Constraints & Average Score & Rank \\
\hline $\begin{array}{l}\text { Incidence of reproductive } \\
\text { disorder }\end{array}$ & 60.65 & 1 \\
Low conception rate & 58.90 & 2
\end{tabular}

\begin{tabular}{lll}
$\begin{array}{l}\text { Less availability of improved } \\
\text { germplasm }\end{array}$ & 51.43 & 3 \\
Problem of heat detection & 50.76 & 4 \\
Poor quality of bulls & 46.12 & 5 \\
$\begin{array}{l}\text { Unavailability of trained } \\
\text { inseminator }\end{array}$ & 31.14 & 6 \\
\hline
\end{tabular}

As per the marketing constraints shown in Table 4, lack of adequate marketing information (62.10), lack of value addition (57.50) and less product diversification (51.20) were prime marketing constraints.

Table 4: Marketing constraints faced by the Gaushalas

\begin{tabular}{lcc}
\hline Marketing Constraints & Average Score & Rank \\
\hline Inadequate market information & 62.10 & 1 \\
Inadequate skill for value addition & 57.50 & 2 \\
Less diversification of products & 51.20 & 3 \\
Delay in payments & 40.50 & 4 \\
Problem of transportation of & 38.70 & 5 \\
products & & \\
\hline
\end{tabular}

The constraints among institutional constraints are shown in Table 5. The major institutional constraints were lack of awareness of new practices (59.74) and lack of improved equipments (58.40), lack of vehicles to bring stray cattle (47.63).

Table 5: Institutional constraints faced by the Gaushalas

\begin{tabular}{lcc}
\hline Institutional Constraints & Average Score & Rank \\
\hline $\begin{array}{l}\text { Lack of awareness of new } \\
\text { practices }\end{array}$ & 59.74 & 1 \\
Lack of improved equipments & 58.40 & 2 \\
$\begin{array}{l}\text { Lack of vehicles to bring stray } \\
\text { cattle }\end{array}$ & 47.63 & 3 \\
$\begin{array}{l}\text { Problem of proper division of } \\
\text { labour }\end{array}$ & 43.00 & 4 \\
$\begin{array}{l}\text { Unavailability of ambulance } \\
\text { Lack of emergency veterinary }\end{array}$ & 44.07 & 5 \\
service & 44.01 & 6 \\
\hline
\end{tabular}

The labour constraints faced by Gaushalas are presented in Table 6 and the major labour constraints were less availability of labour (52.09) and high prevailing wage rates (49.81). Similar findings were reported by Mohi and Bhatti (2006) in Punjab where lack of labour was as major constraints. 
Table 6: Labour constraints faced by the Gaushalas

\begin{tabular}{lcc}
\hline Labour Constraints & Average Score & Rank \\
\hline Less availability of labour & 52.09 & 1 \\
High prevailing wage rates & 49.81 & 2 \\
Low skill of the workers & 48.10 & 3 \\
\hline
\end{tabular}

The waste disposal constraints are presented in Table 7 and inadequate space for disposal of dead animals (51.33) was found as major waste disposal constraints. Similar finding was reported by Kaur et al. (2011) in Punjab. Other constraints were social taboos for use of hoofs, skin of cattle (49.43).

Table 7: Waste disposal constraints faced by the Gaushalas

\begin{tabular}{lcc}
\hline Waste Disposal Constraints & Average Score & Rank \\
\hline $\begin{array}{l}\text { Inadequate space for disposal of } \\
\text { dead animals }\end{array}$ & 51.33 & 1 \\
$\begin{array}{l}\text { Social taboos for the use of } \\
\text { hoofs, skin of cattle }\end{array}$ & 49.43 & 2 \\
$\begin{array}{l}\text { Lack of adequate processing of } \\
\text { waste }\end{array}$ & 49.24 & 3 \\
\hline
\end{tabular}

The financial constraints are given in Table 8 and the major financial constraints were irregular government grants (62.95) and delay in fund availability (46.79) followed by inadequate funds to meet operational expenses (48.41) and lack of ease of finance (41.85).

Table 8: Financial constraints faced by the Gaushalas

\begin{tabular}{lcc}
\hline Financial constraints & Average Score & Rank \\
\hline Irregular government grants & 62.95 & 1 \\
Delay in availability of funds & 46.79 & 2 \\
Inadequate own sources of & 48.41 & 3 \\
finance & & \\
Lack of ease of finance & 41.85 & 4 \\
\hline
\end{tabular}

The animal health constraints are given in Table 9 and the major health issues were fighting injuries (53.85), high cost of veterinary services (52.95) and disease outbreak (50.95). Similar findings were reported by Patel et al. (2013) in Gujarat where more than half of the respondents considered high cost of veterinary services as major problem.

Table 10 shows the overall major constraints of the study area. The overall prime constraint for the Gaushalas was lack of green fodder as Haryana is a green fodder deficit region. High cost of concentrates was next major constraint. This can be due to less funds availability with the Gaushalas. Some Gaushalas could barely meet the fodder demand for Gaushalas; hence, they cannot afford concentrates. Whatever concentrates they feed to milch animals came from charity. The third overall constraint was irregular government grants. It was found that though government was giving grants to Gaushalas, but it was irregular. Thus, its share in gross income of Gaushalas was very low (7 per cent). The next overall major constraint was lack of space. This can be mainly because of increasing number of abandoned and stray animals in the state. Some Gaushalas are keeping animals more than the capacity. The other major overall constraint was inadequate market information. Most of the Gaushalas depended upon public donations and they don't have adequate information regarding product diversification and requirement of people.

Table 9: Animal Health constraints faced by the Gaushalas

\begin{tabular}{lcc}
\hline Animal Health Constraints & Average Score & Rank \\
\hline $\begin{array}{l}\text { Injuries due to infighting or due } \\
\text { to male }\end{array}$ & 53.85 & 1 \\
$\begin{array}{l}\text { High cost of medicines/ } \\
\text { veterinary services }\end{array}$ & 52.95 & 2 \\
$\begin{array}{l}\text { Disease outbreak } \\
\text { Tick/ worm/ parasite infestation }\end{array}$ & 50.95 & 3 \\
$\begin{array}{l}\text { Irregular visits of veterinary } \\
\text { staff }\end{array}$ & 47.05 & 4 \\
\hline
\end{tabular}

Table 10: Major (overall) constraints faced by the Gaushalas

\begin{tabular}{lcc}
\hline Overall Constraints & Average Score & Rank \\
\hline Lack of green fodder & 71.40 & 1 \\
High cost of concentrates & 67.44 & 2 \\
Insufficient and irregular & 62.95 & 3 \\
government grants & 62.55 & 4 \\
Less space & 62.10 & 5 \\
$\begin{array}{l}\text { Lack of adequate market } \\
\text { information }\end{array}$ & & \\
\hline
\end{tabular}

\section{CONCLUSION}

It can be concluded from the present study that lack of adequate shed and open space in Gaushalas were the main constraints among housing constraints. To tackle this problem government can provide land to Gaushala for maintaining continuously 
increasing cattle population. Gaucharan bhoomi or a part of Panchayat land can be transferred to these Gaushalas. Also Gaushalas infrastructure should be built efficiently so as to accommodate adequate number of animals in Gaushalas. Among feeding constraint, lack of green fodder availability, high cost of concentrates were the major constraints which can be overcome by proper utilization of fallow land, wasteland pastures and land unfit for human population. While for concentrates, these should be given at subsidized rates to the Gaushalas. Regarding breeding constraint incidence of reproductive disorder were the important problems which was mainly due to more number of local and non descriptive breeds in the Gaushalas. To tackle this problem, Gaushalas besides sheltering stray animals can also take up the activities of breed conservation and development. Among marketing constraints, lack of adequate market information was found as major constraint. This was mainly because marketing was a secondary source of income and Gaushalas do not give much emphasis on making and selling product. This can be solved by establishing proper market for Gaushala products and promoting them. Regarding institutional constraint, lack of awareness of new practices, lack of improved equipments and lack of vehicle to bring stray animals were found as major problems. Adequate facilities like improved equipments, vehicles should be provided to Gaushalas which cannot afford them. Among labour constraint, less availability of labour was found as major constraint. This can be due to more involvement of labour force in agriculture sector in the study area. Among waste disposal constraint the major constraints were lack of space for disposal of dead animals and less use of hoofs and skins due to social and cultural taboos. The Gaushalas can make use skin and hoofs or they can also sell it to contractors which will help in generating additional income. Among financial constraint, irregular grants given by government was major problem. The Government funding can be increased by allocating a certain portion of funds in the annual budget to the Gaushalas alone. The major animal health constraints were fighting injuries, high cost of medicines and veterinary services. This can be overcome by keeping animals in separate sheds and providing free of cost medicines and other veterinary services as in Gaushalas majority of the animals are infirm, old and diseased which require regular care.

\section{REFERENCES}

Dhindsa, S.S., Nanda, R. and Kumar, B. 2014. Problems and Constraints of Dairy Farming in Fatehgarh Sahiib District of Punjab. Progressive Research, 9(1): 250-252.

Garret, H.E. and Woodworth, R.S. 1969. Statistics in Psychology and Education. Vakils, Feffer and Simons Pvt. Ltd. Bombay 329.

Hedge, N.G. 2010. Forage resource development in India. In: Souvenir of IGFRI Foundation Day. November 52.

Kaur, I., Dhindsa, S.S., Kaur, H. and Singh, P. 2011. Various Constraints of Dairy Farming In Central Zone of Punjab. Journal of Dairying, Foods E Home Science, 30(4): 242 - 245.

Kothari, B.N. and Mishra, N. 2017. Gaushalas, Gosadans, Pinjarapoles, Pasture Land and Fodder Development. Department of Animal Husbandry, Dairying and Fisheries.

Misra, R.K. and Pal, P.K. 2003. Prospects and Constraints of Dairying in Rural Bengal. A case Study. Indian Dairyman, 55(12): 55-59.

Mohi, A.K. and Bhatti, J.S. 2006. Constraints Encountered by Dairy Farmers in Adoption of Improved Dairy Farming Practices. Journal of Food, Dairying and Home Science, 25(1): 47-50.

Nagrale, B.G., Datta, K.K. and Chauhan, A.K. 2015. An analysis of constraints faced by dairy farmers in Vidarbha region of Maharashtra. Indian Journal of Dairy Science, 68(4): 390-394.

Patel, N.B., Saiyed, L.H. Rao, T.K.S., Singh, R.R., Modi, R.J. and Sabapara G.P. 2013. Status and Constraints of Dairying in the Tribal Households of Narmada Valley of Gujarat - India. Animal Science Reporter, 7(3): 83-89.

Singh, M. and Chauhan, A. 2006. Constraints faced by Dairy Owners in Adoption of Scientific Dairy Farming Practices. Indian Journal of Dairy Science, 59(1): 49-51.

$19^{\text {th }}$ Livestock Census, 2012. All India Report. Ministry of Agriculture, Department of Animal Husbandry, Dairying and Fisheries. Krishi Bhawan, Delhi, 2014. 
